
\title{
AKULTURASI BATIK TRADISIONAL JAWA DENGAN CINA
}

01

Dina Dwikurniarini, Agus Murdyastomo, Ririn

\begin{abstract}
Abstrak
Batik merupakan salah satu budaya asli Indonesia yang sudah dikenal sejak lama dan menjadi ciri khas busana tradisional. Dalam perkembangannya batik mengalami akulturasi dengan budaya lain sehingga terlihat dalam perubahan-perubahan motif dan kegunaannya. Paling sedikit ada lima budaya yang mempengaruhi batik tradisional Jawa, yaitu Islam, Cina, Hindu, Budha dan Eropa. Meskipun demikian batik telah diterima sebagai sebuah seni kerajinan yang adiluhung dan justru menjadi ciri-ciri tertentu pada daerah-daerah tertentu yang memiliki batik di Jawa.

Tulisan singkat ini akan mengulas batik sebagai tradisi Jawa yang mempunyai ciri khas tersendiri dan berkembang mengikuti zaman, sehingga terdapat perpaduan anatara tradisi dan modernisasi. Kegunaan batik yang dikembangkan saat ini semakin membuat batik dikenal luas dan untuk kepentingan pasar. Di era global ini akankah batik mempertahankan diri dengan tradisionalnya atau mengikuti perkembangan dunia? Bagaimana dengan nilai filosofisnya apakah akan dipertahankannya, sehingga bermakna bagi pemakainya? Sebaliknya apakah pasar global justru mengurangi makna ketradisionalannya sehingga batik menjadi pelengkap saja atau untuk penuhi kebutuhan semata? Setidaknya jika membeli batik, manusia hanya memanfaatkan semata tanpa mempunyai tujuan yang lebih dalam.
\end{abstract}

\section{LATAR BELAKANG MASALAH}

Semenjak isu batik Indonesia diakui sebagai budaya Malaysia maka banyak orang yang seolah baru sadar bahwa apa yang diakui negara lain itu miliknya. Sebagai salah satu jenis kain tradisional batik banyak digunakan untuk kegiatan adat, sehingga batik juga hanya populer dikalangan orang tua saja. Pengakuan Malaysia akan batik membuat banyak orang berebut untuk memakainya. Batik yang agak terlupakan kembali dicari orang, sehingga mempengaruhi perdagangan batik di Indonesia saat ini. Berbaagi upaya dilakukan untuk mengembangkan kembali pasar batik di Indonesia yaitu seluruh wilayah Indonesia berupaya menunjukkan kembali batik sebagai cirri masing-masing daerah, seperti batik Madura, batik Cirebon, batik Pekalongan, batik Kalimantan, batik Papua, batik Jambi, batik Lampung dan di Yogyakarta terdapat batik Bantul, batik Imogiri, dan batik-batik dengan menggunakan warna alam menjadi ciri tersendiri. Kreasi batik saat ini lebih bervariasi sehinggga angggapan batik itu untuk orang tua mulai bergeser karena anak-anak muda mulai banyak yang memilihnya sebagai pakaian mereka seharaihari. 
Dari perkembangan perdagangan batik di Indonesia saat ini juga muncul produk batik dari Cina. Banyak orang tidak menyadarinya sehingga menganggap sebagai produk dalam negeri dengan kreasi baru saja. Apakah keadaan itu dapat mempengaruhi eksistensi batik itu sendiri atau semakin menenggelamkan batik tradisis Indonesia asli dimasa mendatang. Disini peran dari seniman batik menjadi penting karena dari kreasi merekalah yang akan memepertahankan keaslian batik tradisional Indonesia. Meskipun dunia sudah mengakui bahwa batik adalah asli budaya Indonesia, keaslian itu harus tetap dipertahankan.

Sejarah batik di Indonesia mencatat batik sudah dikenal sejak zaman Hindu. Bukti-buktinya dapat dilihat pada candi-candi peninggalan lampau yang menggunakan batik pada ragam hiasnya. Pada arca Kertarajasa, raja Majapahit I (1216-1231) di candi Ngrimbi dekat Jombang, Jawa Timur diberi hiasan seperti motif batik kawung. Di candi Borobudur dan candi Prambanan pada beberapa pahatannya juga dihias dengan motif-motif batik.Dari peninggalan itu menunjukkan batik memang sudah dikenal sejak berabad-abad lampau dan teori dari J Brandes juga mengatakan bahwa batik betul-betul dari Jawa dan bukan dari India,Memang dalam perkembangannya pengaruh Hindu terdapat dalam motif-motif batik, seperti motif bangunan ibadah agama Hindu. Pengaruh batik tradisional juga terlihat dari unsur-unsur Islam, Cina maupun Eropa. Sejak kapan Cina terlibat dalam perkembangan batik, hal ini bisa ditelusuri dari akulturasi budaya pada motif-motif batik Jawa, demikian juga unsurunsur Islam,maupun Eropa.

Motif batik tradisional tidak diketahui berapa jumlahnya juga siapa yang mencipta juga tidak diketahui secara pasti. Sejarah terjadinya motif batik lebih menceritakan sebagai dongeng yang dihubungkan dengan kehidupan sehari-hari masyarakat Jawa, seperti keadaan alam sekitar dan kejadian-kejadian yang menyangkut kehidupan manusia.Penciptaan sebuah motif batik mengandung tujuan tertentu bagi pemakainya. Corak tertentu diperuntukkan untuk gelar tertentu yang dapat melimpahkannya sebagai pemberian kehormatan. Beberapa motif dipakai untuk acara seperti upacara perkawinan dan upacara adat yang lain.

Cina tidak hanya mempengaruhi batik dalam ragam hias tetapi juga dalam perdagangan bahan batik. Di Yogyakarta tahun 1930 sudah ada perusahaan batik milik pribumi dan orang Cina yang mengusahakan batik halus maupun perusahaan batik cap.Perusahaan batik yang dikelola orang Jawa maupun Cina terletak di kota Yogyakarta seperti di Mantrijeron, Brontokusuman, Karangkajen, Prawitotaman, Kauman, dan beberapa tempat lain. Setelah kemerdekaan perusahaan batik merata diseluruh penjuru kota Yogyakarta dengan pekerja dari Bantul, Kotagede, Sentolo, Imogiri. 


\section{BATIK TRADISIONAL JAWA}

Sejak kapan batik menjadi pakaian tradisional terutama di Jawa, dapat dilihat dari asal usul kata dan sejarahnya. Batik mempunyai banyak pengertian dan arti yang luas, beberapa pengertian diberikan dari akhiran "tik" dari kata menitik atau menetes.Batikan dalam bahasa Jawa berarti seratan, dibatik sama dengan dipun-serat, yaitu diberi gambar dengan lilin. Dari pengertian itu maka batik dapat diartikan sebagai menulis diatas kain dengan menggunakan alat canting dan memakai bahan lilin yang disebut rengrengan dan apabila telah selesai dibatik diberi warna. Dengan demikian batik adalah gambaran diatas kain dengan menggunakan lilin sebagai bahan pencegah meresapnya warna yang tidak dikehendaki ke dalam kain. Alat yang digunakan adalah canting atau cap, kemudian dicelup ke dalam larutan yang telah diberi warna.

Batik bagi orang Jawa adalah kata kerja karena membatik adalah membuat bintik-bintik.Membatik juga berarti menulis karena alat yang digunakan yaitu canting. Canting adalah sebuah alat dari tembaga yang mempunyai satu atau beberapa lubang kecil dan melalui lubang-lubang itu aliran lilin dengan berbagai ukuran dapat keluar dan menempel pada kain. Pegangan dari bambu dan penggunaannya hampir sama dengan alat tulis yang lain. Gambar yang dihasilkan seolah-olah diciptakan dari titiktitik, maka membatik atau mbatik dapat diterjemahkan sebagai sepotong kain yang telah diberigambar dengan titik-titik, atau menggambar dengan garis patah. Batik tulis adalah suatu cara membuat batik dengan canting dan ini dianggap yang paling halus. Cara lain dari pembuatan batik menggunakan cap atau piring tembaga untuk menutup seluruh permukaan kain. Penggunaan cap biasanya untuk produksi dalam jumlah banyak dengan cepat. Cap telah diberi pola batik terlebih dahulu sebelum dicetak pada kain putih, kemudian memberi isian dan diwarnai.

Kain yang selesai dibatik disebut jarit atau jarik, merupakan bahasa Jawa ngoko dan dalam bahasa Jawa Kromo berarti tapih atau bebed,yaitu kain panjang yang dipakai wanita sebagai pakaian adat Jawa. Satu potong kain batik mempunyai ukuran tradisional yang disebut kacu. Kacu adalah sapu tangan yang berbentuk persegi empat, maka sekacu adalah ukuran perseginya mori dan satu potong kain batik memerlukan 2,5 kacu

\section{SEJARAH PERKEMBANGAN KERAJINAN BATIK TRADISIONAL}

Batik telah berabad-abad lamanya dikenal sebagai pakaian adat Jawa yaitu sejak jaman Hindu. Bukti-buktinya dapat dilihat pada candicandi peninggalan zaman kejayaan Hndu dan Budha yang menggunakan motif batik pada ragam hiasnya. Di arca candi Ngrimbi dekat Jombang, Jawa timur diberi hiasan seperti motif batik "kawung", yaitu pada arca Kertarajasa, Raja Majapahit I (1216-1231). Candi Borobudur dan candi Prambanan pada beberapa pahatannya juga dihias dengan motif-motif batik. 
Asal mula seni batik berdasar dua pendapat yang saling bertentangan, pertama mengatakan bahwa batik berasal dari India karena Indonesia pernah berhubungan dengan India; pendapat kedua mengatakan bahwa batik merupakan seni asli Indonesia. G.F. Rouffer berpendapat bahwa asal mulanya seni batik Jawa adalah dari India. Padagang-pedagang India mempengaruhi Jawa dalam agama dan kebudayaan sejak kurang lebih abad ke-4 Pendapat tersebut didukung oleh Fruin Mess yang mengatakan: .... tetapi orang Pasundan meniru juga kepandaian orang Hindu seperti membuat kain batik. Pendapat-pendapat tersebut bertentangan dengan teori Dr. J. Brandes yang mengatakan kalau seni batik betul-betul dari Jawa dan merupakan kebudayaan yang memerlukan banyak belajar dan bukan dari Hindu. Sebelum kebudayaan Indonesia bertemu dengan kebudayaan India, bangsa Indonesia telah mengenal seni membuat batik hanya dalam perkembangannya terdapat pengaruh agama Hindu terutama dalam motif-motifnya. Misalnya pintu gerbang candi telah distilir dan dipakai dalam motif batik Jawa.

Canting diperkirakan asli Indonesia yang digunakan oleh orang Jawa yang ditempat lain tidak ada. Oleh karena itu batik Jawa mempunyai ciri khas karena menggunakan canting. Canting dapat menghasilkan gambar yang rapi dari garis-garis dan titik-titik. Canting diperkirakan sudah dikenal pada abad ke-12 jika dilihat dari motif batik pada ragam hias candi. Kata batik juga diperkirakan dikenal setelah ada canting, karena alat tersebut yang dapat menghasilkan gambar yang bermacam-macam. Sebelum canting dikenal, maka potongan bambu dipakai dengan sendirinya tidak dapat menghasilkan gambar yang rumit.

Jika dilihat dari sejarah perkembangan kerajinan batik di Jawa, maka batik klasik Yogyakarta sudah dikenal sejak berdirinya keraton Yogyakarta pada pertengahan abad ke-18. Batik kraton atau luar keraton mempunyai ciri yang berbeda. Seolah-olah Sultan mengatakan bahwa batik adalah seni kerajaan yang hanya dikerjakan wanita-wanita kerajaan. Keputusan seperti itu memang tidak dapat dipaksakan, karena batik telah begitu akrab dengan rakyat terutama wanita. Raja mengeluarkan peraturan mengenai pemakaian kain batik agar dapat membedakan antara keluarga keraton dengan rakyat kebanyakan. Batik berfungsi sebagai:

\section{a. Pakaian Adat}

Batik tidak dapat dilepaskan dari dunia keraton karena disanalah batik banyak digunakan untuk keperluan adat. Keraton juga merupakan pusat aktivitas kebudayaan dan agama, maka di keraton juga berlangsung upacara keagamaan dan upacara-upacara tradisional, seperti Grebeg, tujuh bulan kehamilan, kelahiran dan lain-lain. Salah satu perlengkapan upacara adalah kain batik, maka kain batik selalu dihubungkan dengan pakaian tradisional karena upacara-upacara tersebut hanya ada dalam kehidupan tradisional.

Kebudayaan lain yang ada dalam masyarakat adalah tari. Keraton juga memiliki kesenian seperti tari. Tari-tarian diselenggarakan untuk menyambut tamu yang berkunjung ke keraton atau untuk menghormati 
sultan. Tari sebagai bentuk kesenian tradisional memakai juga kain batik sebagai pakaiannya. Oleh karenanya kain batik selalu ada dalam kehidupan keraton. Batik merupakan bentuk seni yang digolongkan sebagai seni pakai dan dipergunakan untuk kepentingan praktis seperti untuk pakaian sehari-hari, pakaian adat, dan untuk upacara-upacara adat. para putri bangsawan membatik sendiri untuk suaminya.

\section{b. Sebagai Pakaian Sehari-hari}

Pemakaian kain batik saat ini sudah kurang melekat lagi di dalam masyarakat Jawa karena berbagai pengaruh lingkungan. Pendidikan barat yang mengarah ke paham modern merupakan salah satu sebab timbulnya perubahan dalam cara berpikir masyarakat. Cara berpakaian masyarakat di kota juga mengalami perubahan dan lebih banyak meniru cara berpakaian orang Eropa. Kain batik menjadi tidak dibutuhkan lagi sehingga sebagian besar masyarakat pemakai kain batik tinggal di desa. Kemudian orangorang kota karena adanya perubahan tersebut hanya memakai kain dalam saat-saat tertentu saja seperti dalam upacara resmi.

\section{Akulturasi BatikTradisional dengan Cina}

Pada umumnya batik tradisional memiliki ciri-ciri sebagai berikut:

1. Bentuk dan gaya figuratif dengan corak stilasi dari flora, fauna, dan manusia.

2. Sederhana dalam konsep konfigurasi pencorakan, pada umumnya menggunakan pola simetri.

3. Pencorakan dalam komposisi tertutup.

4. Tata letak corak cenderung menutup seluruh bidang kerja.

5. Corak umumnya bersifat simbolik spiritual

6. Corak dibuat dalam lingkup fungsi-fungsi adati.

Hubungan Indonesia dengan bangsa-bangsa lain telah menimbulkan akulturasi atau culture contact. Proses terjadinya akulturasi memerlukan waktu lama sampai unsur-unsur kebudayaan asing dapat diterima oleh kebudayaan setempat. Batik Jawa mempunyai corak tersendiri, tetapi telah mendapat juga pengaruh luar. Batik Madura misalnya terpengaruh Cina. Umumnya corak batik Madura berupa lukisan binatang mitos yang terdapat dalam dongeng, juga ada corak daun dan bunga. Tata warna dan teknik menggambar yang rapih dan halus mirip lukisan pada porselin Cina. Timbulnya variasi dalam corak batik menjadikan batik dapat dibedakan menjadi: sebagai pakaian adat, pakaian sehari-hari, dan keperluan lain, seperti seprei, taplak meja, tirai.

Dengan demikian batik Jawa dapat dibedakan dalam empat ciri pokok yaitu: (a) ciri Hindu, mirip daun dan bunga tanjung maupun bercorak bangunan candi; (b) ciri Islam, mirip dengan daun dan bunga anggur; (c) ciri Cina, bercorak kepala atau telinga singa; (c) ciri Eropa, motif beraneka seperti rangkaian bunga. Morif sebuah batik terdiri dari unsurunsur pola yaitu: (a) unsur pokok pola disebut ornamen pokok; (b) ornamen pengisi yang tidak membentuk arti atau jiwa pola; (c) untuk memperindah pola secara keseluruhan dipakai isian atau isen. 
Pengaruh alam sangat menonjol dalam pola batik yang berujud bunga, ikan, burung dan pohon anggur. Masuknya Islam di Jawa pada sekitar abad ke-15 memberi pengaruh lain dalam pola batik. Kepercayaan Islam tidak memperbolehkan adanya gambar manusia atau makhluk. Hal ini dimaksudkan agar manusia jangan kembali lagi ke zaman jahiliyah. Oleh karena itu seni batik mencari jalan untuk menghindari larangan tersebut. Menggambarkan binatang dan makhluk hidup lainnya dengan distilir yaitu melingkari pola-pola bunga dan daun yang rumit disekitarnya. Pengaruh Eropa dalam motif batik berujud tumbuhtumbuhan dan kebanyakan dipakai sebagai bahan pakaian sehari-hari.

\section{Akulturasi Batik tradisionaDengan Cina}

Pengaruh Cina telah disesuaikan dan diterima sebagai ketrampilan seniman Jawa untuk membentuk bagian keseluruhan dari pola batik, seperti pola mega mendung. Corak Mega Mendung merupakan salah satu corak batik yang mendapat pengaruh Cina yang sangat populer. Pada batik pesisiran ornamen-ornamen yang menampilkan adanya pengaruh Cina antara lain Ular, Singa, Naga, Burung Phoenix, Bunga-bunga khas Cina dan ornamen-ornamen seperti pada keramik Cina. Batik pengaruh Cina menerapkan warna-warna cerah dan warna-warna pastel. Batik-batik dengan pengaruh Cina banyak dijumpai di Pekalongan, Cirebon, Kudus, dan Demak.

Berikut ini beberapa motif batik yang mendapatkan pengaruh dari Cina:

1. Motif Mega Mendung

Salah satu pola batik khas dari Cirebon yang sangat kental dengan pengaruh budaya Cina adalah batik Mega Mendung. Dalam sejarahnya pola Mega Mendung ini dikembangkan oleh Putri Ong Tie, seorang puteri Cina yang menjadi istri dari Sunan Gunung Jati. Ong Tie sangat menaruh perhatian pada bidang seni khususnya keramik. Motif-motif keramik yang dibawa dari negeri Cina ini akhirnya mempengaruhi motif-motif batik hingga terjadi perpaduan antara kebudayaan Cirebon-Cina, salah satunya adalah motif mega mendung atau awan-awanan. Pada motif ini dapat dilihat baik dalam bentuk maupun warnanya bergaya selera Cina. Motif mega mendung melambangkan pembawa hujan yang dinanti-nantikan sebagai pembawa kesuburan dan pemberi kehidupan. Motif ini didominasi warna biru, mulai biru muda hingga biru tua. Warna biru tua menggambarkan awan gelap yang mengandung air hujan, pemberi penghidupan, sedangkan warna biru melambangkan cahaya kehidupan. Saat ini motif mega mendung banyak dibuat dalam berbagai warna cerah, seperti motif di bawah ini. 


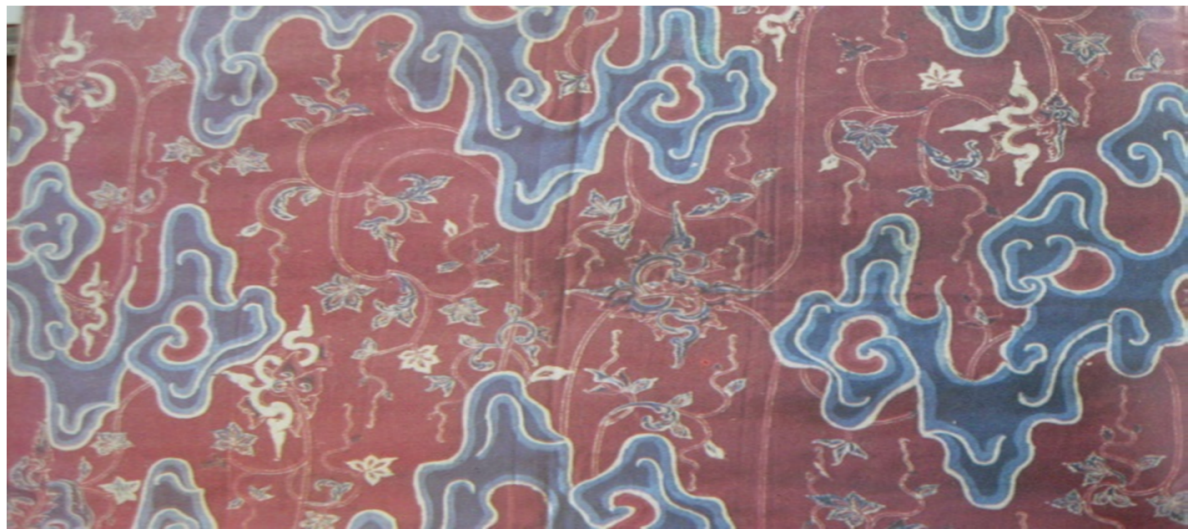

2. Motif Banji

Motif Banji mungkin merupakan tipe tertua motif ornamen pada batik. Gambar dasarnya adalah swastika, persilangan sederhana dengan panjang yang sama, masing-masing lengan memiliki titik sudut arah yang sama. Desain banji yang lebih kompleks berbentuk pola geometris yang terdiri dari elemen ornamen sederhana berupa serangkaian garis yang saling terhubung pada sudut 90 derajat, selalu mendasarkan pada bentuk swastika yang orisinil.

Penggunaan banji pada seni ornamental di Asia Tenggara dimulai sejak masa Hindu Budha, bahkan beberapa bukti menunjukkan telah muncul lebih awal. Swastika berasal dari bahasa Sanskerta yang berarti "sesuatu yang baik", akan tetapi kata banji sendiri merupakan kata yang berasal dari Cina. Simbol Cina ini sama dengan versi Sanskerta yaitu kebahagiaan, panjang umur, dan kemakmuran. Pola banji kerap muncul pada dekorasi batik pesisir.

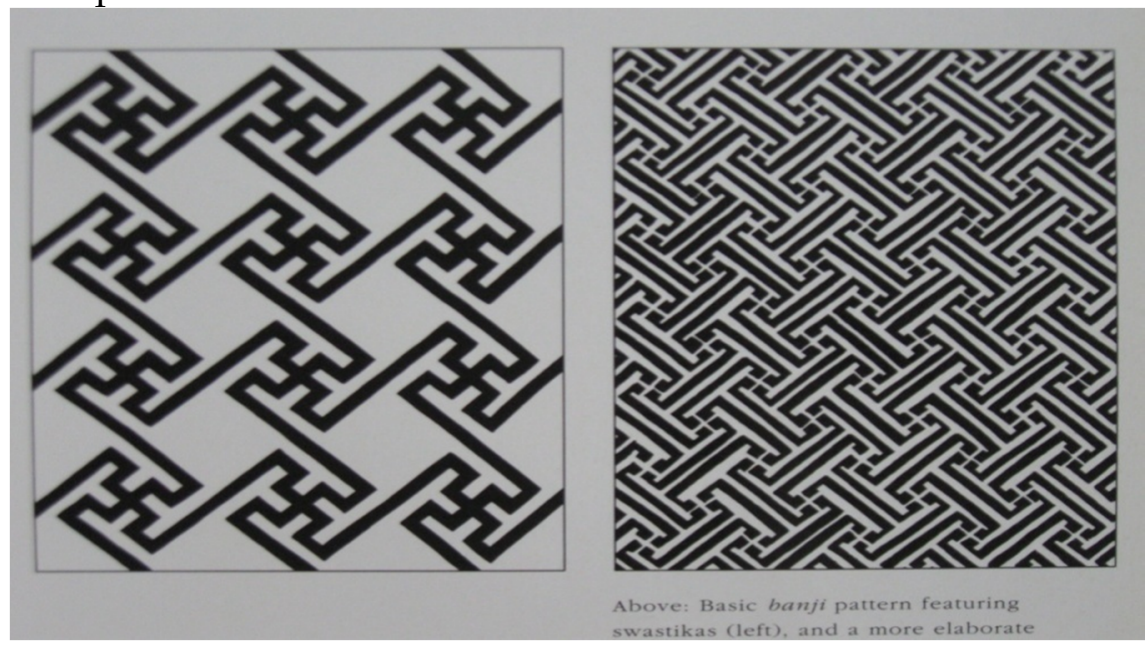

Batik dengan pola banji yang menggambarkan swastika 

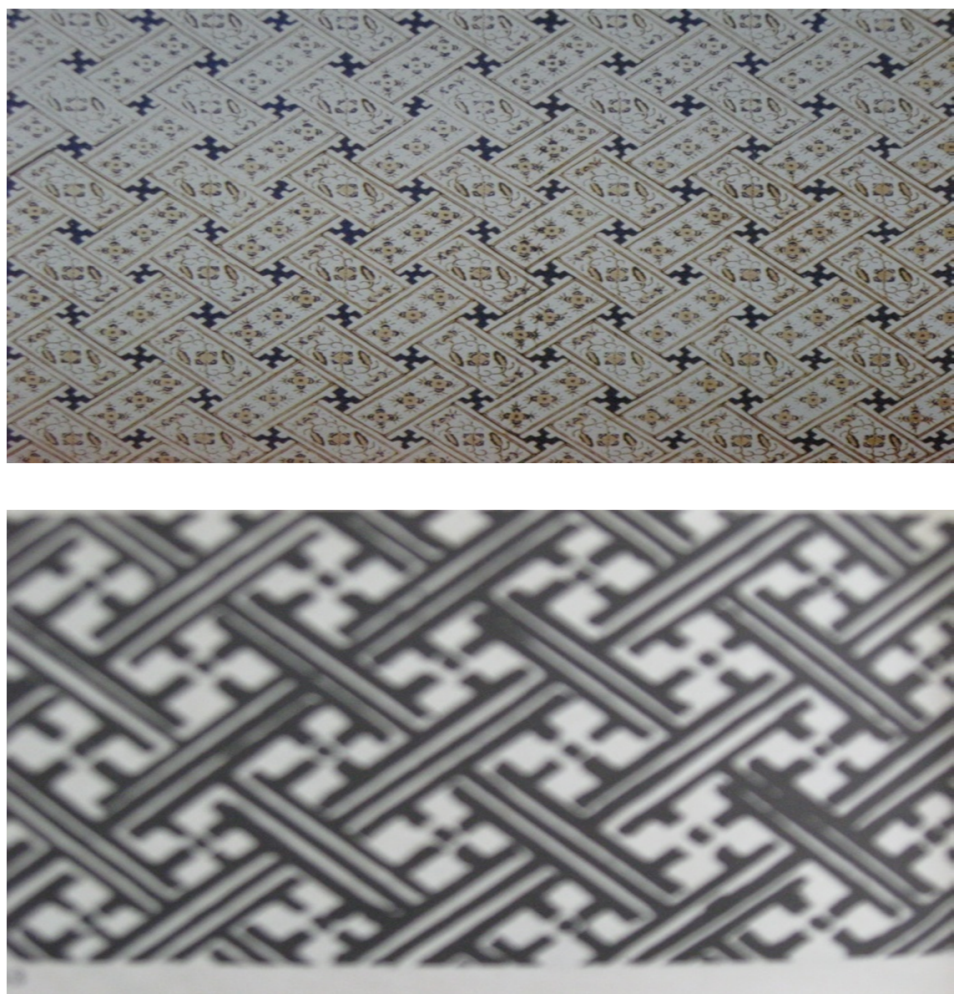

Keterangan: kain panjang dengan pola banji yang dibuat di Yogyakarta, keduanya dari awal abad ke-20.

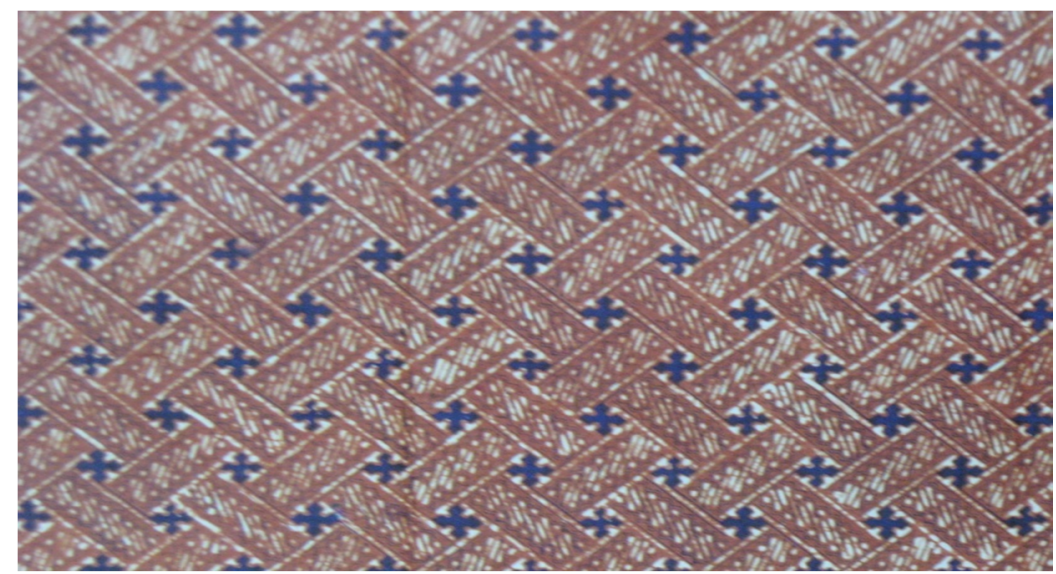

Kain panjang dengan pola banji yang dibuat di Surakarta dengan latar coklat-merah.

Sumber:

Pepin van Roojen, Batik Design (Netherlands: Pepin Press, 2001), hlm. 48- 49. 


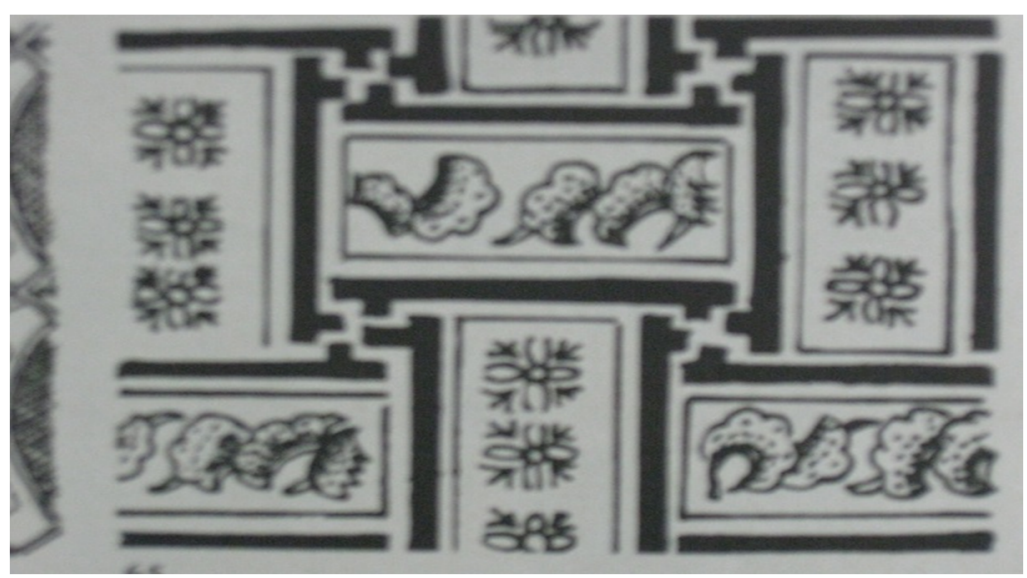

3. Motif Binatang

Motif binatang banyak digunakan dalam batik Jawa tetapi juga dalam batik Cina. Namun demikian penggunaannya sangat berbeda. Seni motif dekoratif yang paling sering digunakan dalam batik Cina adalah ular, macan, singa, naga, burung-burung cinta dan phoenix. Motif-motif ini menemukan sendiri jalannya ke dalam desain batik pesisir bersama dengan motif bunga-bunga Cina. Perpaduan antara motif Jawa dan Cina menghasilkan desain bunga yang sangat berbeda dengan motif bunga yang sebelumnya dikenal di Asia Tenggara. Ornamen-ornamen yang ditemukan dalam keramik Cina merupakan sumber-sumber inspirasi yang lain. Selanjutnya penggunaan warna-warna yang cerah mendominasi batik Cina, seperti hijau, biru, merah, kuning, oranye dan warnawarna pastel. Motif batik Cina juga suka disebut "esok sore" yaitu penggunaan latar yang berbeda dalam satu kain.

Pengaruh Cina di sepanjang pantai utara lebih kuat daripada di Surakarta dan Yogyakarta. Pengaruh Cina di Yogyakarta dan Surakarta lebih banyak berupa motif banji, misalnya banji bengkok yang sebenarnya adalah motif kawung dengan variasi. Sejak abad ke-18 batik di Pekalongan dan kota-kota pesisir lain dikuasai oleh komunitas Cina. Pembuatan batik di Lasem hampir seluruhnya berada di tangan orang-orang Cina. 
INFORMASI, No. 1, XXXIX, Th. 2013

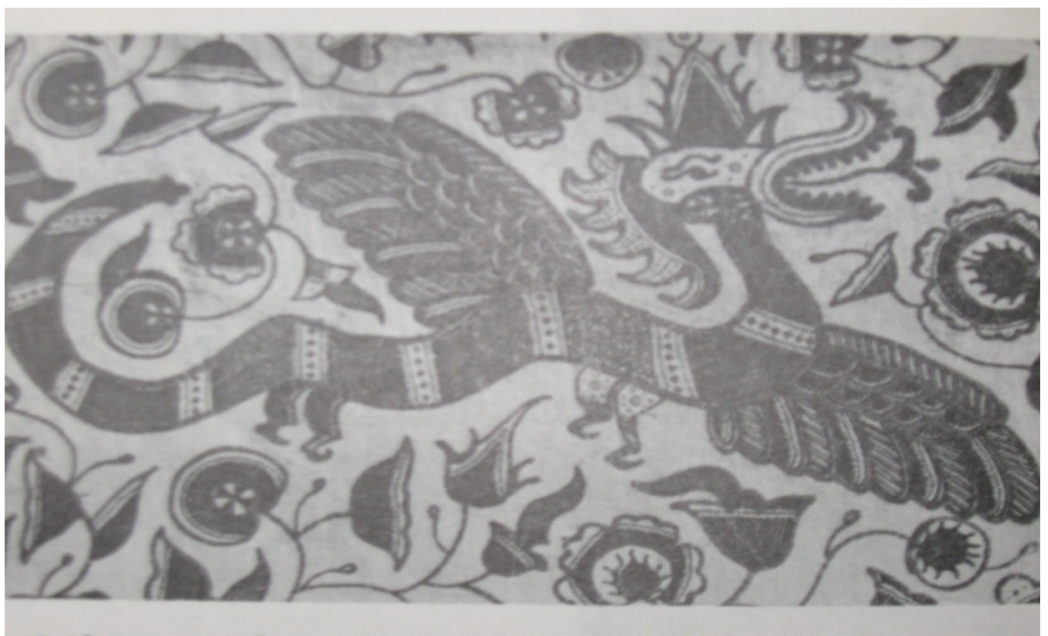

Batik naga bertolo

Sumber: Pepin van Roojen, Batik Design (Netherlands: Pepin Press, 2001), hlm. 82.

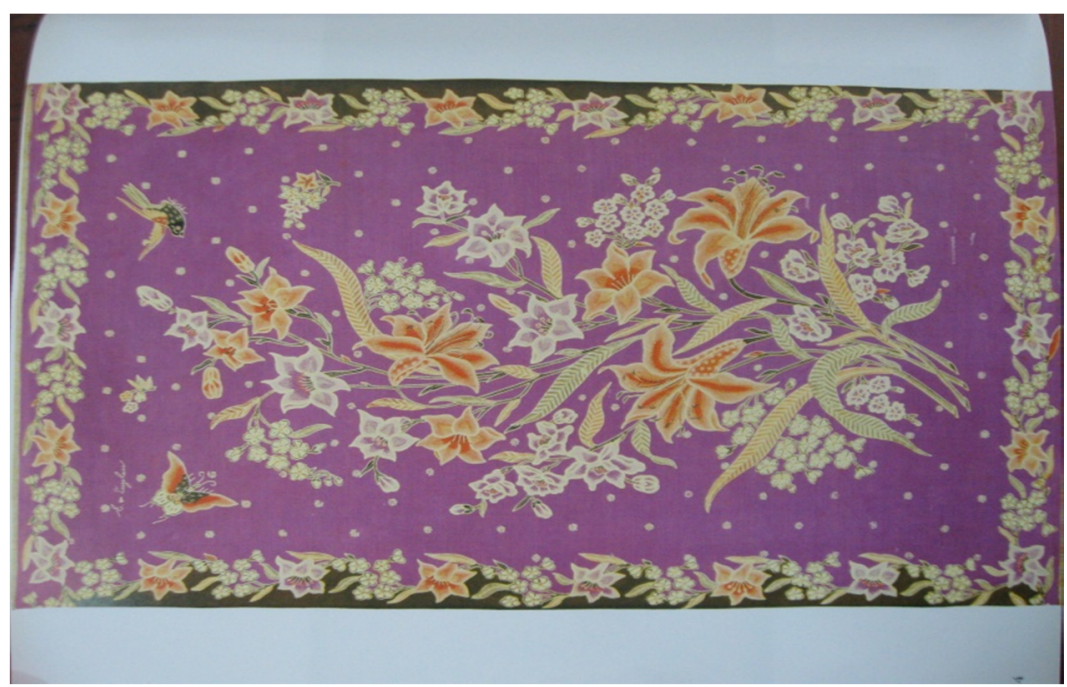

Batik motif Bunga

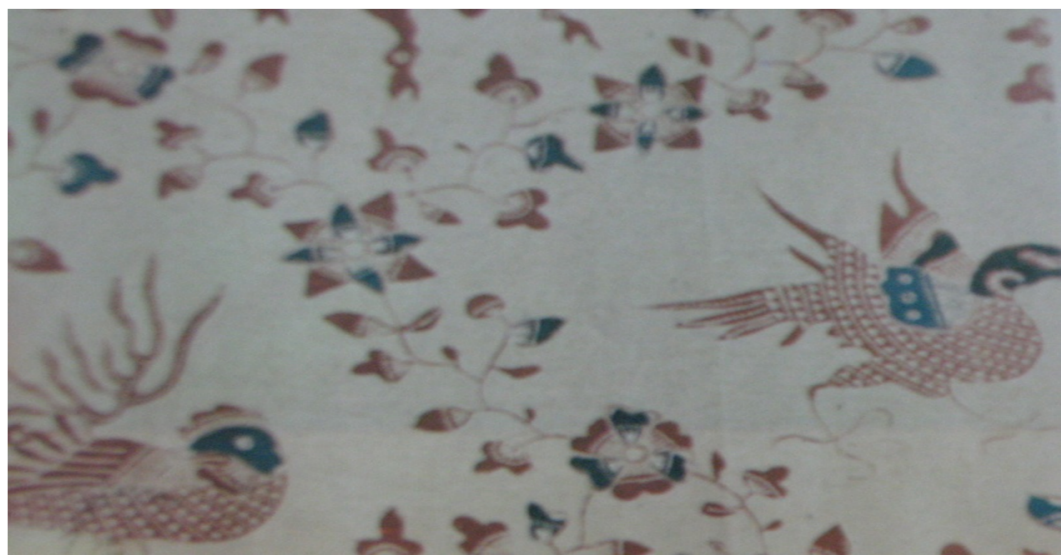

Batik motif binatang dan bunga 


\section{Tantangan Batik di Era Global}

Masuknya pengusaha Cina dalam produksi batik abad ke-19 membawa banyak perubahan. Orang-orang Cina adalah pembuka jalan dalam perdagangan batik. Sebelum timbul perdagangan batik, wanita desa menghasilkan kain batik untuk dipakai sendiri atau dijual ke desa lain, sekarang diorganisir pengusaha Cina untuk dipasarkan secara luas. Pengunaan cap untuk produksi batik menyebabkan semakin luasnya perdagangan batik, tetapi batik tradisional yang dikerjakan dengan tangan tetap menjadi kerajinan yang digemari oleh golongan mampu.

Saat ini batik dari Cina telah menyerbu pasar Indonesia dengan harga yang luar biasa murahnya. Hal ini tentu merupakan tantangan berat bagi pengusaha batik Indonesia. Konsumen tentu akan lebih memilih barang dengan harga yang lebih murah. Produk batik Cina dapat dijual dengan harga yang relatif murah karena dalam pengerjaannya Cina menggunakan teknik printing untuk batik yang mereka produksi. Dengan dicetak langsung pada kain maka batik dapat diproduksi secara massal dalam waktu yang relatif singkat. Dengan adanya penghematan waktu dan tenaga tentu mampu mengurangi biaya produksi. Perbandingan harga bisa mencapai hampir $50 \%$.

Sebaliknya batik produk Indonesia cenderung lebih mahal karena beberapa hal. Pertama produksi batik menggunakan teknik canthing dan cap yang tentu saja memakan waktu dan tenaga. Produk hand made tentu lebih bernilai dibandingkan dengan produk massal. Kedua, hampir 80\% bahan baku pembuatan batik di Indonesia harus diimpor dari Cina, misalnya benang, sutera, dan cat. Dengan masuknya batik buatan Cina yang memiliki harga jual lebih murah tentu menjadi ancaman bagi para perajin batik Indonesia.

Permasalahan lain yang dihadapi dalam pengembangan batik adalah adanya krisis regenerasi.Sebagai contoh kaum muda di kampung batik Trusmi di Cirebon dan Indramayu Jawa Barat yang cenderung enggan melanjutkan usaha batik tulis yang dirintis pendahulu mereka. Seorang pengusaha batik bahkan harus mempekerjakan pembatik dari luar daerah misalnya dari Pekalongan Jawa Tengah untuk membatik di tempatnya. Regenerasi batik belum berjalan baik. Pembelajaran otodidak yang diwariskan turun temurun dari orang tua dan anaknya kurang efektif. Pembatik yang aktif bekerja di Trusmi umumnya berusia di atas 40 tahun. Tenaga muda diperlukan agar batik Cirebonan bisa kreatif dan inovatif dalam menghadapi gempuran dari Cina.

Salah satu upaya yang dapat dilakukan adalah dengan memasukkan ketrampilan membatik dalam pendidikan formal. Beberapa sekolah sudah menjadikan kegiatan membatik sebagai kegiatan pilihan dalam program ekstra-kurikuler. Pemerintah perlu mendirikan sekolah ketrampilan khusus yang mendidik generasi muda menjadi perajin-perajin batik yang mahir. 


\section{Simpul Akhir}

Batik sebagai hasil karya bangsa Indonesia yang sudah diakui dunia menunjukkan suatu keunikan tersendiri. Sejarah batik yang telah dikenal lebih dari dua belas abad telah diolah dan diterima sebagai kebudayaan masyarakat Indonesia. Motif-motif batik tradisional Jawa mendapatkan pengaruh dari kebudayaan lain Khusus untuk kebudayaan Cina terlihat pada motif yang tidak biasa digunakan dalam batik tradisional dengan pengraruh Hindu, Budha dan Islam yang telah diterima sebagai motif tradisional. Motif yang terpengaruh Cina seperti: motif Banji, seperti swastika dengan berbagai ragamnya; "mega mendung" atau "esok sore" memang menjadi ciri khas dan itu terlihat pada batik Cirebonan dan Pekalongan. Pada motif-motif lain seperti penggambaran binatang, bunga atau alam juga menjadi ciri khas Cina, seperti pada batik Madura. Selain itu juga nampak pada penggunaan warna yang juga tidak biasa digunakan dalam batik tradisional yang menggunakan hanya warna atau "latar putih" untuk batik Yogyakarta dan "latar ireng" untuk batik Surakarta. Batik pengaruh Cina menggunakan warna-warna cerah seperti hijau, biru, merah, kuning. Oleh karena itu batik tradisional digunakan untuk upacaraupacara adat, keagamaan. Batik pengaruh Cina lebih banyak digunakan sebagai pakaian sehari-hari baik untuk pria maupun wanita. Sifat kain batik yang digunakan sehari-hari tersebut maka kadang kain-kain dibuat massal dengan menggunakan cetak atau printing yaitu memadukan dengan canting..

Saat ini batik menjadi populer kembali setelah Malaysia mengklaim batik sebagai asli negaranya. Kejadian itu paling tidak ikut menentukan pasar batik saat ini. Selain itu akhir-akhir ini juga muncul batik Cina dipasaran dalam negeri. Batik Cina sebernanya juga sebagai batik tradisional, tetapi ada kecenderungan Cina memproduksi batik yang dikerjakan oleh pembatik-pembatik tradisional dan seolah-olah sebagai batik Cina. Hal itu tentu saja akan sangat merugikan produk dalam negeri karena tak mampu bersaing dengan produsen Cina.

Solusi yang dapat dilakukan adalah mencegah semua itu dengan semakin menggiatkan produksi batik tradisional yang kadang masih terkendala modal. Untuk membuka investor-investor batik paling tidak semakin sering dilakukan pameran batik diseluruh penjuru negeri ini. Dengan makin banyak orang tahu batik semakin banyak yang ingin memiliki atau mengembangkannya.

\section{DAFTAR PUSTAKA}

Angelino, P De Kat, Batik Rapport, Weltevreden: Landsdrukkerij, 1931.Art and Crafts in Indonesia, Jakarta: Departemen of Information Republic of Indonesia, 1974.

“Batik Cirebonan Terkendala Regenerasi”, Kompas, 22 Juli 2011. 
Belfer, Nancy, Disigning in Batik and the Tie Dye, Worecter Massachusette: Davis Publication Inc., $1972 .^{1}$

Biranul Anas Zaman, "Batik dalam Dinamika Budaya”, makalah seminar 19 Mei 200..

B. Martin dan R.P. Warindo Dwidjoamiguno, Belajar Melukis Batik beserta Motif-motif Batik, Yogyakarta: Nur Cahaya, tt

Brandes, J. "Een Jayapattra of Acte van eene Rechterlijke Uitspraak van Caka 849". Tijdshrijf voor Indische Taal-Land-en Volkunde, vol. XXXII, 1889.

Burger, D.H., Sedjarah Sosiologis Ekonomis Indonesia, Djakarta: Pradnja Paramita, 1970.

Darmo, "Sinjang Parang Rusak ingkang Katah Gadah Dongeng", Majalah Jaya Baya No. 18 Th. XIX Januari 1965.

Etty Herawati, Kain dan Pakaian Tradisional Madura, Jakarta: Dinas Museum dan Sejarah, 1979.

Gootschak, Louis, Mengerti Sejarah, terjemahan Nugroho Notosusanto, Jakarta: UI Press, 1983.

Hamzuri, Batik Klasik, Jakarta: Jambatan, 1981.

Holt, Claire, Art In Indonesia Continuitica and Changes, Ithaca, USA: University Press, 1967.

Jasper, J.J. dan Mas Pirngadie, De Batikkunst, 'S Gravenhage: Kunsdrukkerij v/h Mouton \& Co., 1916.

Joseph Fischer, ed., Treads of Tradition, Los Angeles: Andreson Lithograph Company, 1979.

Kertscher, W, Perindustrian Batik di Pulau Djawa, diterjemahkan oleh Poey Ken Sin, Leverkusen: Pabrik Tjat Pewarna, 1954.

Kopenberg, S., De Javanche Batik Indonesia, tanpa kota terbit, penerbit dan tahun terbit.

Kota Yogyakarta 200 Tahun, Jakarta: Panitia Peringatan 200 tahun Kota Yogyakarta, 1956.

Labin, Baverly, "Batik Tradition in the Life of the Javanese ", dalam Joseph Fischer, ed., Treads of Tradition, Los Angeles: Andreson Lithograph Company, 1979. 
Leslien H. Palmier, Social Status and Power in Java, London: the Ithlone Press, 1960.

Majalah Jaya Baya No. 18, Th. XIX, 1965.

Mess, Fruin, Sedjarah Tanah Jawi Jilid I, diterjemahkan oleh S. M. Latief, Weltefreden: Balai Pustaka, 1921.

Paulus, J, “Batikken" dalam Enciclopedie Nederlandsch Indie II, Leiden: Martinus Nijhof en J.E. Brill, 1917.

Pepin van Roojen, Batik Design, Netherlands: Pepin Press, 2001.

Republik Indonesia Propinsi Djawa Tengah, Djakarta: Kementrian Penerangan, 1952.

Rouffaer, G.P. en Joyboll, H.H., De Batikkunst in Nederlandsche-Indie en HaarGescheidenis, Utrecht: A Gosthookte, 1914.

Selo Soemardjan, Perubahan Sosial di Yogyakarta, Yogyakarta: Gadjah Mada University Press, 1981.

Sudjoko, “Adibusana Tanpa Tara, Makalah dalam Sarasehan Seni Rupa dan Batik, Balai Kesenian Nasional Indonesia di Yogyakarta 1983.

Sutjipto Woerjosaputro, Bunga Rampai Sedjarah Budaja Indonesia, Djakarta: Djembatan, 1964.

S. Soetopo, “Batik”, Majalah Batik No 9, 1956.

SK Sewan Susanto, Seni Kerajinan Batik Indonesia, Yogyakarta: Balai Penelitian Batik dan Kerajinan, Lembaga Penelitian dan Pendidikan Industri, Departemen Perindustrian RI, 1973

Van der Hoop, A.N.J. Th. a. Th., Ragam-Ragam Perhiasan Indonesia, Koninklijk Bataviasch: Genootscap van Kunsten et Wetenchappen, 1949.

Van Hoeve, Ensiklopedi Indonesia, Bandung: Gravenhage, 1980. 